\title{
SUB-ALTER(NATIVE) CINEMA: REVISITING INDIA'S HISTORY OF IDENTITY REPRESENTATION THROUGH INDEPENDENT FILM
}

\author{
Viralika Arora \\ UWC East, Singapore \\ DOI: 10.46609/IJSSER.2021.v06i06.022 URL: https://doi.org/10.46609/IJSSER.2021.v06i06.022
}

\begin{abstract}
Socio-economic inequalities in the Indian context owing to the long history of discrimination in Indian society are underrepresented in mainstream cinema and discourse. Major production houses shy away from promoting or blatantly misrepresent marginalized voices and narratives because of their goal of generating profits by pandering to mainstream narratives. In such a space the onus of representing marginalized voices has been taken up by independent filmmakers through different periods in the history of Indian filmmaking. More recently, economic, technological, and academic advancements have contributed to a growth in the representation of subaltern narratives in cinema. Moreover, the spaces in indie cinema are more accessible to individuals coming from backward castes, as discrimination in Bollywood and other mainstream film industries continue to be rampant. This paper explores the representation of marginal voices through indie cinema, and the challenges faced by it- particularly the rise of the far-right Hindutva movement in India and the impending regulations on online streaming platforms.
\end{abstract}

Keywords: Cinema, Society, Bollywood, Films, revenue.

\section{Introduction}

Independent or indie cinema refers to all feature films, short films, and movies that are made beyond the major film studio system of a society. In today's globalized free-market socioeconomic system, studio conglomerates, more commonly known as 'majors' produce and develop a significant portion of all cinema. In the United States, major studio houses collectively command $80-85 \%$ of annual revenue (Schatz, 2005). This creates an oligopoly in the marketwith a few major production houses collectively commanding the narratives and media consumed by local and global communities. Independent or 'indie' films operate beyond this ambit and are considered to be free from the oligopolistic influence of the major production houses. Cinema continues to hold cultural and artistic value in society. However, over the past century, cinema has been commercialized to a much greater extent in comparison to other forms 


\section{International Journal of Social Science and Economic Research}

ISSN: $2455-8834$

Volume:06, Issue:06 "June 2021"

of art. Whilst commercialization and inclusion into the economic system have been inevitable in today's global market economy, the rate at which cinema has been commercialized is distinguishable. The brand value commanded by personalities in cinema is a testament to the same. In such a space, mainstream cinema has started to serve a purpose other than artistic expression and creativity- profits. The emergence and eventual dominance of production houses in different economies throughout the world further contributed and accelerated this process (Callahan, 2001). The demands and leanings of the market started to influence cinema more than the creators of those supposed pieces of artistic expression. In such a space, Indie cinema holds special value and significance in society. Because of its detachment from mainstream studio houses and the profit motive in general, critics and academics believe that indie filmmakers have a greater avenue to represent their artistic instinct and ability through cinema (Callahan, 2001).

The significance of indie cinema extends beyond simply promoting and preserving the artistic liberties of filmmakers. They are often the only sources of representing counter-narratives and subaltern narratives in media by providing them with a platform that 'major' production houses do not. The locus of power in modern societies lies with a particular socio-economic group or community, by the virtue of their historic status in contrast to the rest of the society, especially oppressed and marginalized communities. These sections of society dominate major positions of power- in the economy, in politics, and given its cultural, social, and economic significance in cinema. Any narrative that threatens the legitimacy and power of emancipated social groups is quickly shrugged under the carpet in mainstream media, most so in cinema. Whilst this process is not absolute, and progressive social movements within and beyond cinema have made it more inclusive in liberal democracies, cinema in developing countries like India is yet to reach that level when it comes to the most uncomfortable truths of society (Bharatvaraj \& Subramani, 2018). Whilst it is unfair to assume that production houses, that control the narratives of most movies produced in a society intentionally stifle subaltern opinions and stories, their inability to stand up to larger power structures, which is causation of the profit motive in cinema has contributed to indie movies being perceived as a truer representation of social realities. Despite the dominance of majors in Indian cinema for the past few decades, indie cinema has picked up pace in recent years. Technological developments have made movie-making a more accessible art form, whilst growing literacy and social consciousness around issues which are underrepresented in mainstream narratives have pushed filmmakers of all communities to pursue cinema in line with their artistic and experiential interests- something that is impossible when filmmakers, writers, and actors are reliant on profit-driven production houses (Kirsner, 2008).

\section{Background}

Indian society is heterogeneous and any generalization passed on the same is bound to have exceptions due to differences in geographic, economic, and even social realities. However, 


\section{International Journal of Social Science and Economic Research}

ISSN: $2455-8834$

Volume:06, Issue:06 "June 2021"

Indian society, since the early Vedic age, has been segmented into castes. These castes were made rigid by the later Vedic age, and with the gradual abolishment of caste mobility communities and society became hierarchized- with some social groups holding power over others. Hundreds of years later 'upper' caste communities, by the virtue of their historic privilege hold significant sway over narratives and policy in the Indian context. A similar comparison can be drawn on issues of gender, since Indian society, similar to most of the world, has followed a patriarchal setup that seeks to oppress and subjugate women, as well as gender and sexual minorities. These social forces and narratives have historically created policies, systems, and even cultures that promote discrimination in subtle and explicit ways. Whilst India has adopted a liberal and democratic constitution, which not only protects but provides for provisions to promote the rights of the historically marginalized, this constitution has not been actualized for a significant section of marginalized groups, who continue to face overt and sometimes explicit forms of oppression.

Indian cinema at its inception was not inspired by profits like it is now but strived to emulate western cinema or represent indigenous narratives, cultures, and realities. Silent cinema and the early talkies were committed to and promoted Gandhi's idea of anti-untouchability, a stance that was considered radical in many sections of Indian society (Bharatvaraj \& Subramani, 2018). Hindi cinema explored nuanced social issues of caste and culture in films such as 'Achhut Kanya' and 'Sujata', which were released in 1936 and 1959 (Gokulsing \& Dissanayake, 2004). The production and eventual release of Satyajit Ray's masterpiece Pather Panchali gave rise to 'Parallel Cinema' - a movement that sought to explore lived experiences and socio-political contexts (Joshi, 2007). Movies within parallel cinema, including 'Achut Kanya' followed Ambedkarite themes and even had Dalit protagonists (Bharatvaraj \& Subramani, 2018). However, the investment in parallel cinema started to yield lesser returns because of its reluctance to give in to the profit-making frenzy that was overtaking the movie industry in India. Whilst parallel cinema declined in the 1990s, Indian cinema- primarily Bollywood and the South-Indian movie industries (which cumulatively dominate more than $85 \%$ of the market) cultivated the 'masala' brand of cinemas- termed so because of the presence of all themes including tragedy, drama, comedy, melodrama, and romance (Khanna, 2003). These movies gained immense popularity amongst the Indian audience and propelled the movie industry into an unprecedented frenzy of growth. Studios became large-scale industries whilst actors gained the same repute as politicians and sports personalities in what led to the creation of the Indian film industry' (Chaudhuri, 2015). Eventually, movies started being produced only to make money which made them susceptible to market demand. The Indian audience, at the turn of the century, was not receptive to progressive or even realistic descriptions of life. Uncomfortable truths around social realities in India became unpopular in Indian cinema, which started focusing more on dramatic, often unrealistic stories that culminate in a happy ending. Most importantly, 


\section{International Journal of Social Science and Economic Research}

ISSN: $2455-8834$

Volume:06, Issue:06 "June 2021"

there was an absence of progressive voices in the industry, which meant that all events were analyzed through a patriarchal and Brahmanical lens (literally and figuratively). Hence even when caste or gender oppression was discussed, it was done in a way that was convenient to the privileged filmmaker, his colleagues, and his producers. Even when movies like Lagaan attempted to explore untouchability, these ventures either lacked depth and nuance or promoted negative stereotypes about Dalits. Dalit characters, even when shown in a positive light, lacked self-confidence and free-will, often depending on their upper-caste counterparts for emancipation and growth (Bharatvaraj \& Subramani, 2018).

\section{Discussion}

The decline of Parallel Cinema in India before the turn of the century, combined with the increasing commercialization of Indian cinema due to liberal economic reforms of the 1990s solidified the inability of mainstream cinema and major production houses to represent marginalized voices. In such a space, independent filmmakers took up the onus of promoting subaltern narratives, with many finding critical success at the national and international level. 'Masaan', an indo-french movie that was made outside the influence of major production houses of India in 2015, succeeded in showing a more accurate portrayal of the struggles of Dalits and women in less developed contexts of India (Young, 2015). Pivoting away from the conventional norms of happy endings, drama, and romance, Masaan sought to represent the everyday struggles of oppressed castes in India, which are systematically and deliberately kept outside mainstream discourse (Ford \& Richards, 2015). Indian movies reflect the linguistic diversity of India, and whilst Bollywood and its major production houses control a significant chunk of the market, non-Hindi films are often more successful in representing lived experiences of marginalized communities. Sairat, a romantic tragedy produced by Nagraj Manjule provides an accurate description of inter-caste marriages and the stigma that surrounds them, especially in semi-urban and rural areas (Sahani, 2016).

The theme of inter-caste marriages and the struggles involved in the same is recurring in indie movies exploring caste struggles, as Masaan, Sairat, and Fandry (also directed by Nagraj Manjule) attempt to show lived caste realities whilst touching on themes of romance, which is more palatable to the mainstream Indian audience. Other movies (all of which are nonBollywood, and to a great extentindependent' in their production) include Chauranga (2014), Court (2014), the Punjabi movie Anhey Ghore Da Daan (2011), and the English-Malayalam film Papilio Buddha (2013) (Bharatvaraj \& Subramani, 2018). Films like Harud (2010) and I am (2010) deal with youth politics affected by terrorism and judiciary violence in Kashmir- a region that has been witnessed immense conflict, terrorism, and violation of human rights, often sponsored by India and Pakistan- the two nation-states that seek to establish control over it (Haq, 2016). Kashmir continues to be a polarizing issue in India, especially given allegations of human 


\section{International Journal of Social Science and Economic Research}

ISSN: $2455-8834$

Volume:06, Issue:06 "June 2021"

rights violations by the Indian Army and the Indian State. Similar to 'Masaan', 'I am' successfully shows the intricate working of multiple narratives, as it not only engages with the adverse realities faced by the youth in Kashmir due to political instability, but it also stirs a conversation about homosexuality and the lack of legal representation of marginalized groups such as the LGBTQ community. Dhobi Ghat (2013), despite having influences from mainstream Bollywood is another indie film that accurately portrays struggles associated with caste, class, and gender in urban India (Haq, 2016). Parallel cinema emerged in different film 'industries' at different points in time. In Tamil Nadu, the release of Sethu in 1999 was followed by other movies that had raw and shocking themes which were underrepresented in mainstream cinema. Be it the depiction of caste brutality in rural Tamil Nadu through Paruthiveeran (2007), the depiction of shocking yet prevalent honor killings in Kadhal (2004), or other similar movies including Katrathu Tamizh, Veyil, Anjathey, Subramaniapuram, Poo, and Naan Kadavul (Gopalkrishnan, 2019).

The economic development witnessed by India has widened inequalities, but it has also contributed to the emergence of a middle class. Combined with technological advancements and the spread of the internet and streaming services, and the emergence and popularity of liberal arts education and the exploration of cinema from a critical and academic perspective, this has contributed to more people having the creative, economic, and logistical ability to make films. Global investment has allowed Indian filmmakers to explore themes and narratives that mainstream cinema rarely touches upon. This has caused the indie film scene in India to thrive but has also had a surprising impact on mainstream Bollywood films. Hollywood has started to pay more attention and credence to marginalized struggles (primarily relating to race and gender) over the past few years- owing to the development of progressive and contentious politics. Whilst Bollywood is still a long way behind, production houses have started to tap into underrepresented narratives by combining them with the popular Masala formula that generates commercial success. Aamir Khan's Peepli Live provides an insight into the experiences of farmers and how that links to the growing rates of farmer suicide in India.

\section{Conclusion}

Whilst mainstream production houses have barely begun their exploration of subaltern narratives, indie films provide nuanced insights into the lived experiences of marginalized voices in society. Over the past decade, the development and popularity of streaming services including Netflix and Amazon Prime (which have also assumed the role of film producers) have contributed to the ability of filmmakers to make cinema and television shows outside the control of major production houses. The present central government of India is unapologetically rightwing, which has somewhat curbed the development of cinema that attacks right-wing bigotry, in particular the Brahmanical Patriarchy perpetuated by it. Despite this, shows including 'Sacred 


\section{International Journal of Social Science and Economic Research}

ISSN: $2455-8834$

Volume:06, Issue:06 "June 2021"

Games' and 'Leila' have challenged the growing threat represented by the dominant forces in India's political ecosystem. However, these expeditions have been met with stiff resistance, not just from mainstream production houses but also the government and state agencies. This political threat, which is tantamount to suppressing the Right to Freedom of Speech of individuals, is novel for indie filmmakers, whose previous constraints were limited to the lack of economic resources and backlash from mainstream media. As the Indian government has introduced new legislation to govern the content on streaming platforms, the recent growth and emergence of indie cinema can be threatened or even shut down completely (Raman, 2020).

Even beyond the growing state interference and attempts to curb any narrative that threatens their Hindutva ideology, other problems within the Indian film industry continue to stifle the representation of marginalized voices. Research suggests that only 6 of the lead characters in the nearly 300 Bollywood movies released between 2013 and 2014 belonged to backward castes. It is argued that the systematic exclusion of Dalits from development parameters combined with the bias and discrimination prevalent in the film industry has resulted in a hegemony of cinema spaces by upper-caste Hindus. This has naturally led to Indian cinema being castediscriminatory at its worst and caste-blind at its best. Even when big names in Bollywood including Amitabh Bachchan and Aamir Khan have undertaken projects to represent oppressed voices in projects including Eklavya and Lagaan, the resulting cinema has often led to the perpetuation of negative stereotypes against Dalits (Bharatvaraj \& Subramani, 2018). Moreover, the representation of backward castes there is antithetical to the anti-caste movement pioneered by Ambedkar and Phule, which has formed the primary rallying point for Dalit activism in India.

There is a need for public and non-governmental agencies to invest in subaltern and independent cinema. Given the impact that cinema has on society, this could lead to growing social consciousness around the adverse living conditions faced by the oppressed in India. Moreover, there is a need to increase the participation of backward castes in filmmaking in an attempt to improve the lens through which sensitive topics of caste and gender are discussed. Whilst this would be a challenge in the present political climate of India, the success of similar movements in countries like the United States (which has also been under the control of a far-right government recently) provides a path for the Indian film industry to follow so that it can be inclusive truly represent the diverse identities and narratives that constitute India.

\section{Bibliography}

Bharatvaraj, S.S.G ., and Subramani, R. (2018). Manifestation of Subaltern Narratives in Cinema. American International Journal of Research in Humanities, Arts and Social Sciences 
International Journal of Social Science and Economic Research

ISSN: 2455-8834

Volume:06, Issue:06 "June 2021"

Callahan, P. (2001). Don't Lose It At The Movies The Brothers McMullen and Blair Witchyes. Waterworld II-no.

Chaudhuri, D. (2015). Written by Salim-Javed: The Story of Hindi Cinema's Greatest Screenwriters. Penguin

Ford, R., and Richards, R. Cannes: 'Son of Saul,' 'Masaan' Take Fipresci Prizes. The Hollywood Reporter, 23rd May 2015

Gokulsing, K.M., and Dissanyake, W. (2004). Indian Popular Cinema: A Narrative of Cultural Change. Trentham Books

Gopalkrishnan, S. (2019). Marginalised in the New Wave Tamil Film: Subaltern

Aspirations in three films by Bala, Kumararaja and Mysskin. Rupkatha Journal on Interdisciplinary Studies in Humanities

Haq, S. (2016). Independent Cinema in India:An Emerging Cinematic Form. Südasien-Chronik South Asia Chronicle

Joshi, L.M. (2007). India's Art House Cinema. British Film Institute

Khanna, A. (2003). The Business of Hindi Films: Encyclopaedia of Hindi Cinema: historical record, the business and its future, narrative forms, analysis of the medium, milestones, biographies. Encyclopadia Britannica

Kirsner, S. (2008). Inventing the Movies: Hollywood's Epic Battle Between Innovation and the Status Quo, from Thomas Edison to Steve Jobs. CinemaTech Books

Raman, A. Explained | How will the government regulate online news and OTT platforms? The Hindu, 11th November 2020

Sahani, A. Discrimination exists everywhere in India: Nagraj Manjule. The Indian Express, 6th March 2016

Schatz, T. (2009). New Hollywood, New Millennium: Film Theory and Contemporary Hollywood Movies. Routledge

Young, D. Masaan: Cannes Review. The Hollywood Reporter, 24th May 2015 